\title{
REDUCING ENVIRONMENTAL POLLUTION BY BIOCONVERSION OF HUGE QUANTITY OF ORGANIC WASTES INTO MUSHROOMS - AN ENVIRONMENTAL IMPACT
}

\section{Bhandari P.R., ${ }^{2}$ Wadhai V.S. and Kamdi R.R.}

\author{
1Sevadal Mahila Mahavidyalaya, Nagpur (M.S) India \\ 2Sardar Patel Mahavidyalaya, Chandrapur (M.S) India \\ ${ }^{3}$ Anand Niketan College, Warora (M.S) India \\ Email: prbhandariO2@gmail.com
}

\begin{abstract}
Mushroom cultivation technology is friendly to the environment. The production of edible and medicinal mushrooms utilising, for example, paddy straw, cotton wastes, water hyacinth, tree saw dust, and various categories of refuse and lignocelluloses wastes, could readily be adopted in Indian communities in sophisticated, but low technology approaches. The spent substrate left after harvesting the mushrooms, which is entangled with innumerable mushroom threads (collectively referred to as mycelia) will have been biochemically modified by the mushroom enzymes into a simpler and more readily digestible form, which is thus more palatable to livestock, when used as a livestock feed supplement. It has been revealed recently that mushroom mycelia can play a significant role in the restoration of damaged environments. Saprotrophic, endophytic, mycorrhizal, and even parasitic fungi/mushrooms can be used in mycorestoration, which can be performed in four different ways: mycofiltration (using mycelia to filter water), mycoforestry (using mycelia to restore forests), mycoremediation (using mycelia to eliminate toxic waste), and mycopesticides (using mycelia to control insect pests). These methods represent the potential to create a clean ecosystem, where no damage will be left after fungal implementation.
\end{abstract}

Keywords: Mushroom, Solid Lignocellulose waste, Environmental pollution

\section{Introduction:}

Reducing Environmental Pollution by bioconversion of huge quantities of organic Wastes into Mushrooms. Organic solid wastes are a kind of biomass, which are generated annually through the activities of the agricultural, forest and food processing industries. They consist mainly of three components cellulose, hemicelluloses and lignin (Beelman R. B. and D. J. Royse. 2006). The general term for these organic wastes is lignocelluloses. It is common knowledge that lignocelluloses wastes are available in abundance both in the rural and urban areas. They have insignificant or less commercial value and certainly no food value, at least in their original form. When carelessly disposed of in the surrounding environment by dumping or burning, these wastes are bound to lead to environmental pollution and consequently health hazards. It should be recognised that the wastes are resources out of place and their proper management and utilization would lead to further economic growth as well(Beelman R. B. and D. J. Royse. 2006).

\section{Materials and Method:}

Huge quantities of lignocellulosic and other organic waste residues are generated annually through the activities of agricultural, forest and food processing industries. In 1999, more than 3,000 million tons of paddy straws were available in the urban area, and about half of these residues remain unused. In addition, cottonseed straw, tons of paddy straw and soya bean straw. Million tons of sawdust, and wood chips are also available. All these lignocelluloses waste residues can be collected and used as substrate growing mushrooms. Otherwise, would cause health hazards due to burning. The fungal organism Pleurotus sajor-caju and Pleurotus florida are also known as Grey Oyster Mushroom or Indian Mushroom, are well acquainted with temperature and moisture of these atmosphere through year except 
Month of April and may because the temperature rises up to $45^{\circ} \mathrm{C}$.

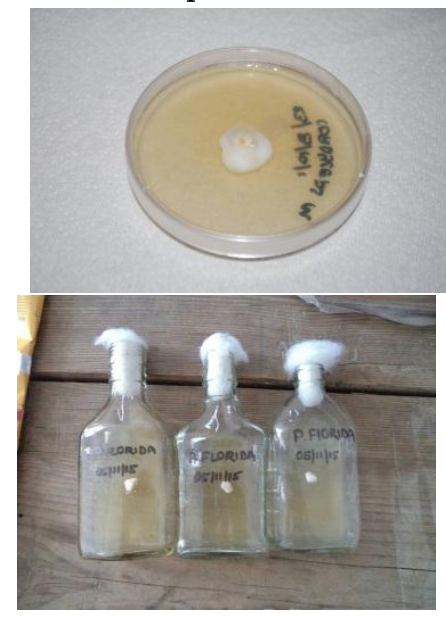

Growth and Culture of Pleurotus sajorcaju on PDA growth media

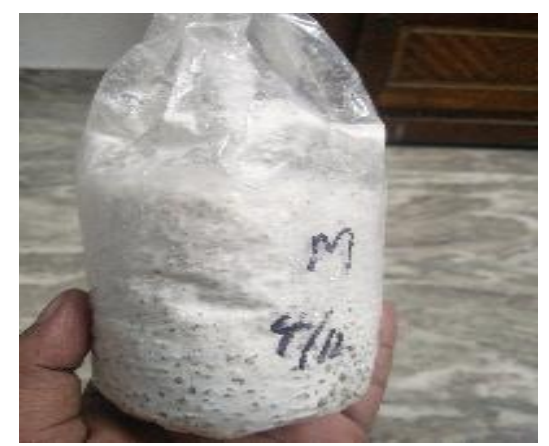

Mother Spawn of Pleurotus

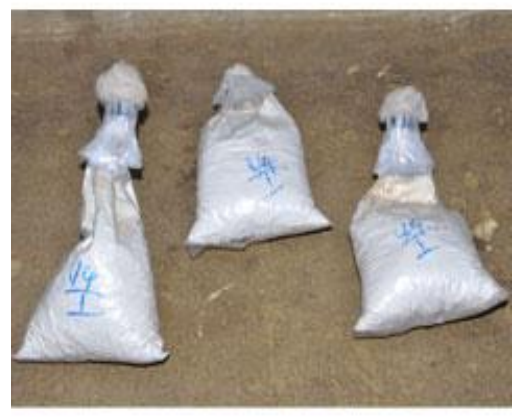

Working Spawn of Pleurotus

\section{Results and Discussion:}

Oyster mushroom enzymes can break down lignin, cellulose and hemicelluloses present in these organic materials into simpler molecules, which the mushrooms then use for their growth and metabolism. Lignocellulosic compounds are complex and insoluble (Miles, P. G. and S. T. Chang. 1997). They can be treated by various chemical methods, with dilute hydrochloric acid and calcium chloride to increase the digestibility and nutritional qualities, and even to form sugars to serve as carbon sources (Mizuno, T., H. Saito, T. Nishitoba and H. Kawagishi. 1995). However, these chemical methods are tedious and costly. Furthermore, treatments to eliminate adverse side effects of the chemicals are also very complex. In contrast, mushroom cultivation techniques have become significantly important in recent years in improving nutritional quality and upgrading the economic value of the solid organic wastes. Mushrooms with other fungi are presently only organisms that can synthesize and excrete the relevant hydrolytic and oxidative enzymes that enable them to degrade complex organic substrates into soluble substances which can then be absorbed by the mushrooms for their nutrients (Dewhurst M. 2002).

The ability of the different mushroom species to utilize various substrates will depend on both mushroom-and substrateassociated factors. For example, examination of the lignocellulolytic enzymes profiles of the three important commercially cultivated mushrooms exhibit varying abilities to utilise different lignocellulosics as growth substrate.

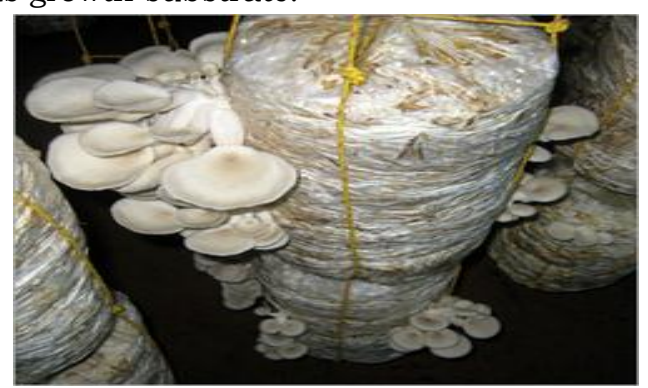

Laboratory cultivated Oyster Mushrooms

Environmental Impact: Recycling of Organic Wastes into Oyster mushrooms, Biofertilizer and Biogas The ultimate aim in the applied aspects of any scientific endeavour is to integrate wherever possible the various disciplines of science as well as the technological processes in order that maximum benefits accrue from such efforts. Combined production of mushrooms, biogas and biofertilizer from the rural and urban organic wastes should be one of the aims of such integrated schemes that can 
eventually be put into profitable operation. Though the conventional and established approaches towards the production of food, fertilizer and fuel exist, the explosive growth of the population vis-a-vis the rapid depletion of conventional fuel resources leads mankind to look for alternative sources for food, fertilizer and fuel. Even though man has been harvesting mushrooms as food from wild sources from times immemorial, their nutritive value was not assessed and their production under controlled conditions was not undertaken until recent decades (Bennett, J. W. and L. L. Lasure. 1991).

Composting as Manure: The lignocellulosic substrate used for Mushroom production and which is left after harvesting of the mushrooms can be used as Compost for soil conditioning. It should be noted that this compost besides being rich in Nitrogenous material contains partly degraded lignocellulosic components, which when combined with animal dung or human excreta in a biogas digest would yield not only biogas but also a good quality organic nitrogenous fertilizer in the form of sludge (Elliott, T. J. 1982). The sludge from the biogas plant as a nitrogenous fertilizer is far more beneficial than the compost from which it has been derived. Part of the biogas that is produced in the vicinity of the mushroom house can also be conveniently used for pasteurization of the mushroom bed material and maintenance of the optimal temperature in the mushroom house as well. It is therefore suggested that an integrated approach in the production of mushroom, biofertilizer and biogas should be considered as a feasible approach for the rural and urban lignocelluloses Waste utilization and disposal. This is the "Zero Emission or Total Productivity" concept. It is Said "The earth cannot produce more: Man has to do more with what the earth produces" (Pauli, 1996, Chang, 2007).

Restoration of Damaged Environment by Mushroom Mycelia Mushroom cultivation technology is friendly to the environment. Mushroom mycelia can produce a group of complex extracellular enzymes which can degrade and utilize the Lignocelluloses wastes in order to reduce pollution(Cai Y. J.,
J. A. Buswell and S. T. Chang. 1994). It has been revealed recently that mushroom mycelia can play a significant role in the restoration of damaged environments. Saprotrophic, endophytic, mycorrhizal, or even parasitic fungi/mushrooms can be used in mycorestoration, which can be performed in four different ways mycofiltration (using mycelia to filter water), mycoforestry (using mycelia to restore forests), mycoremediation (using mycelia to eliminate toxic waste, and mycopesticides (using mycelia to control insect pests). These methods represent the potential to create the clean ecosystem, where no damage will be left after fungal implementation (Stamets 2005).

\section{Conclusion:}

The importance of Oyster mushroom are:

$>$ Oyster Mushrooms can serve as food, as tonic, and as medicine. A regular intake of Mushrooms can make you healthier, fitter, and happier. They can make you live longer, and always look younger.

> Oyster Mushrooms are biota characterized by wonder. They rise up from lignocellulosic Wastes, yet they become so bountiful and nourishing.

> Oyster Mushrooms are environmentally very friendly. They biosynthesise their own food From agricultural crop residues, which would otherwise cause health hazards? And their spent composts/substrates can be used as animal feed, biofertilizer and biogas.

> Oyster Mushrooms can serve as agents for promoting equitable economic growth in society.

$>$ The significant aspect of applied mushroom biology is using the Biota in creating a pollution-free and beneficial environment. These three components of applied mushroom biology are closely associated with three aspects of wellbeing - food shortage, human health and environmental pollution. One of the most significant benefits of mushroom cultivation is their ability to create a pollution free and friendly environment.

\section{Acknowledgements:}

First of all, I would like to take this opportunity to express my sincere thanks to Prof. Pravin Charde, Principal Sevadal 
Mahila Mahavidyalaya, Nagpur for having involved me in Oyster mushroom cultivation and Spawn production technology. I am grateful also to who helped me enthusiastically on all aspects during the development of this project, and who has shown a great interest in the mushroom project.

\section{References:}

Beelman R. B. and D. J. Royse. 2006. Selenium enrichment of Pleurotus cornucopiae (Paulet) Rolland and Grifola frondosa, S. F. Gray mushrooms. Intl. J. Med. Mushroom P. 77-84.

Bennett, J. W. and L. L. Lasure. 1991. More Gene Manipulations in Fungi. Academic Press,INC. New York, USA.

Cai Y. J., J. A. Buswell and S. T. Chang. 1994. Production of cellulases and hemicellulases bythe straw mushroom, Volvariella volvacea. Mycol. Res. 98: 10191024.

Chang, S. T. 2007. Mushroom cultivation using the "ZERI" principle: potential for application in

Brazil Micol Apl. International, P. 33-34.

Chang, S. T. \& T. H. Quimio (eds.) 1982. Tropical Mushrooms--Biological Nature and Cultivation Methods. The Chinese University Press, Hong Kong. 493 pp.
Dewhurst M. 2002. Phase III -the future? The Mushroom J. 626, 17-18.

Elliott, T. J. 1982. Genetics and breeding of cultivated mushrooms. In "Tropical Mushrooms" edited by S. T. Chang and T. H. Quimio. The Chinese University Press, Hong Kong.

Miles, P. G. and S. T. Chang. 1997. Mushroom Biology: Concise Basics and Current Developments. World Scientific. Singapore, 194p.

Mizuno, T., H. Saito, T. Nishitoba and $H$. Kawagishi. 1995. Antitumour- active substances from mushrooms. Food Reviews International 11:23-61.

Pauli G. 1996. Breakthroughs: what business can offer society, Epsilon Press, Surrey, UK.P. 241

Stamets, P. 2005. Mycelium Running: How Mushroom Can Help Save the World. Ten Speed Press, Berkeley and Toronto, 574pp. 